\title{
Objective Structured Professional Assessments for Trainee Educational Psychologists: an Evaluation
}

Sandra Dunsmuir*a ${ }^{*}$ Cathy Atkinson ${ }^{\mathrm{b}}$, Jane Lang ${ }^{\mathrm{a}}$, Amy Warhurst ${ }^{\mathrm{c}} \&$ Sarah Wright $^{\mathrm{d}}$

${ }^{a}$ Educational Psychology Group, Division of Psychology and Language Sciences, University College London, 26 Bedford Way, London WC1H 0AP. Emails:

s.dunsmuir@ucl.ac.uk and jane.lang@ucl.ac.uk

${ }^{\mathrm{b}}$ School of Environment, Education and Development, University of Manchester, Oxford Road, Manchester, M13 9PL. cathy.atkinson@manchester.ac.uk

${ }^{c}$ Faculty of Humanities and Social Sciences, University of Winchester, Winchester SO22 4NR. Email: Amy.Warhurst@winchester.ac.uk

${ }^{d}$ Faculty of Social, Human and Mathematical Sciences, University of Southampton, Southampton SO17 1BJ. Email: $\underline{\text { S.F.Wright@ } \text { soton.ac.uk }}$

* corresponding author

Date accepted for publication in Educational Psychology in Practice: 28 $^{\text {th }}$ May 2017 


\section{Objective Structured Professional Assessments for Trainee}

Educational Psychologists: an Evaluation

Objective Structured Professional Assessments (OSPAs) were developed and evaluated at three universities in the UK, to supplement supervisor assessments of practice on placement. Participating second year students on three educational psychology doctoral programmes $(n=31)$ and tutors $(n=12)$ were surveyed. Scenarios, developed with experienced practitioners, were considered authentic and relevant. Tutor feedback indicated that the marking scheme was a good basis for judgements, but required further calibration and standardisation. Strengths and limitations relating to authenticity of scenarios and practical arrangements were identified. Students considered OSPAs to be a valid assessment of communication and perspective taking skills, although some found them to be anxiety provoking. Levels of authenticity and complexity were deemed appropriate, although there were concerns over time allowed and how the assessment criteria were interpreted. The discussion highlights how OSPAs address issues relating to assessment reliability by improving objectivity, reducing bias and providing uniformity to student assessment experiences.

Keywords: assessment, educational psychology training, simulated consultations, scenarios, competencies

\section{Introduction}

\section{Professional practice assessment within educational psychology training}

Within initial UK educational psychology (EP) training, professional competence is usually assessed via practice placement. However, national and international surveys of practitioner psychologists, have reported that trainee educational psychologists' (TEPs) professional competence is not adequately assessed on placement (Scott, Pachana \& Sofronoff, 2011; Woods, 2013). Typically, judgements are based on a sample of practice observations undertaken by placement supervisors, a non-standardised method reliant on one individual's perspective. Within clinical 
psychology training, Gonsalvez and Freestone (2007) scrutinised 291 end of placement reports over 12 years, reporting that relationship factors were influential and associated with positive results, with few average and below average judgements recorded. Gonsalvez and Freestone (2007) argued that this potentially limited opportunities for trainees to receive critical appraisal and guidance in developing professional competence. Despite such indications of positive bias and lack of specificity, the supervisor's report remains the main assessment method of professional competence in clinical psychology training (Yap, Bearman, Thomas \& Hay, 2012) and also educational psychology training. Other assessment methods, such as written examinations and coursework assignments, have been found to be inadequate or insufficient in assessing professional practice competence (Rushforth, 2007; Miller, 1990; Watson, Stimpson, Topping \& Porock, 2002) and theoretically-based examinations (such as multiple-choice assessments), can 'cue' students (Rushforth, 2007; Schuwirth \& van der Vleuten, 2003). There are therefore, shortcomings with the range of assessment methods used within professional training and a need to consider alternative ways of augmenting those currently in use.

\section{Objective Structured Clinical Examinations in professional training}

A combination of continuous assessment in practice and the use of an objective structured protocol are required for fair, reliable and valid assessment of competence (Rao, 2005). Within the medical field, the Objective Structured Clinical Examination (OSCE) was introduced by Harden, Stevenson, Downie \& Wilson (1975) in order to measure key components of clinical performance which could not be assessed reliably in clinical settings and also could not be captured by traditional cognitive testing (Sloan et al., 1996; MacRae, Cohen, Regehr, Reznick \& Burnstein, 1997). The aim of the 
OSCE is to assess student competencies in a range of simulated conditions (Watson et al. 2002), combining the reality of live clinical interactions, the standardisation of problems, and the use of multiple observations of each student (Hodges, Regehr, McNaughton, Tiberius \& Hanson, 1999). The original OSCE design (Harden et al., 1975) comprises 16 stations, each lasting five minutes, with students moving one from to the next. Each involves a standardised clinical task - some including simulated patients and some requiring written short-question papers, or questions pertaining to physical data, such as X-rays or photographs. Assessment is standardised, with preagreed scoring criteria.

The value of the OSCE as an assessment tool is that it allows for much greater level of examiner objectivity when compared with supervisor and written assessments (Rushforth, 2007; Newble, 2004; Schuwirth \& van der Vleuten, 2003; Watson et al., 2002); a reduced level of examiner bias due to the use of multiple examiners (Bartfay, Rombough, Howse \& Leblanc, 2004; McKnight et al., 1987); uniformity of students' experiences and examiners (McKnight et al., 1987); and assessment of a greater range of skills (McKinght et al., 1987; Watson et al., 2002). Additionally, studies have shown that the process is viewed positively by both students and teaching staff (Roberts \& Brown, 1990; Ross et al., 1988) and can increase students' learning motivation (Bartfay et al., 2004). Immediate feedback on performance has also found to be advantageous (Biran, 1991; Black \& Harden, 1986; Harris \& Miller, 1990). However, research has shown that the OSCE should be utilised only as part of a variety of assessment methods (e.g. McKinley \& Boulet, 2004; Carraccio \& Englander, 2000; Miller, 1990).

The disadvantages of the OCSE are also acknowledged. These include heavy demands on teaching staff in terms of setting-up and facilitating the OSCE process, and resource costs in terms of staffing, venue hire, training of and payment to (real or 
simulated) patients (Bartfay et al., 2004). Tsai (2004) suggested when unsatisfactory test-retest reliability has been recorded, this may be due to inconsistency between patients (real or simulated) and a single examiner at each station. In order to ensure higher inter-rater reliability rates, it is recommended that there should be two examiners at each station (Humphris \& Kaney, 2001) and random quality checks between examiners or second markers (Rushforth, 2007).

\section{Student feedback}

A number of studies have sought to appraise the student experience of the OSCE assessment process (Yap et al., 2012; Troncon, 2004; Alinier, 2003; Hodges et al., 1999; Biran, 1991). Feedback suggests that students are generally favourable towards OSCEs; in particular, they appreciate the scenarios as a good learning opportunity (Yap et al., 2012; Alinier, 2003; Biran, 1991), authenticity of the vignettes (Yap et al., 2012; Hodges et al. 1999), immediacy of examiner feedback (Yap et al., 2012; Alinier, 2003; Biran, 1991), and may even find the experience fun (Biran, 1991; Jewel 1988; Malik, Manchanda, Deepak \& Sunderam, 1988). However, students also reported the OSCE process to be stressful (Yap et al., 2012; Troncon, 2004), the time allowed inadequate (Troncon, 2004; Yap et al., 2012), observer presence intimidating (Troncon, 2004), and inconsistency between examiners (Yap et al., 2012). Additionally, some students reported that they had insufficient preparation via mock-examinations (Yap et al., 2012), and that different OSCE stations might be required for students at differing academic stages (Hodges et al., 1999).

Increasingly, the OSCE structure is being adapted for use in other disciplines, including psychiatry (Hodges, Hanson, McNaughton \& Regehr, 2002), clinical psychology (Yap et al., 2012), and electrical engineering (Alinier \& Alinier, 2006). 
This paper reports a project which sought to adapt OSCEs for use with TEPs. The OSCE structure was modified and the process called Objective Structured Professional Assessment (OSPA). The structure of the OSPAs, as experienced by TEPs is described in the following section.

\section{Structure of the OSPA}

OSPAs were developed by tutors at three universities and piloted with Year 2 TEPs. Full details of the development phase are available at www.ucl.ac.uk/ospaproject. At the outset, two medical advisors with extensive experience of participating and running OSCEs were consulted to give advice on the number and timing of stations, staffing requirements, room and equipment requirements, general scenario content, assessment frameworks, OSPA co-ordinator role and responsibilities and adaptations required for EP training. It was decided that the simulated consultations would occur at four stations each with a different focus: Initial Consultation, Assessment and Explanation, Action Planning, Communication and Ethics (see Figure 1). Authorship of the stations was carried out by university tutors from each of the participating universities, who met to agree the assessment process. Scenarios were calibrated to ensure assessment criteria were explicit and linked to scenario content, to ensure fairness and consistency in application. 
Figure 1. The OSPA carousel

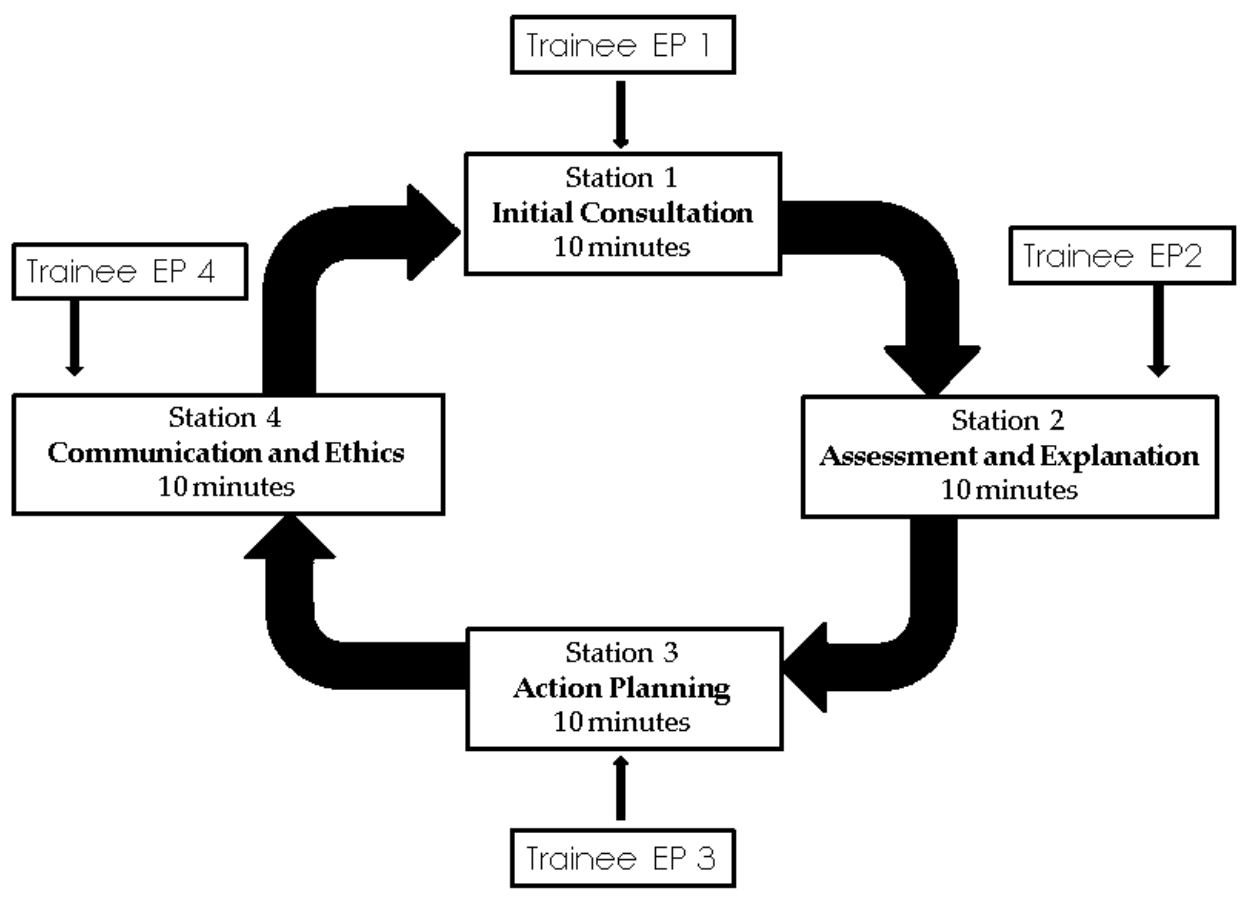

The content of the scenarios was based around practice issues, and sought to assess the competencies required for practice with young people aged between 16-25 years (Atkinson, Dunsmuir, Lang \& Wright, 2015). An example of an OSPA communications and ethics station is presented on the OSPA web-site at https://www.ucl.ac.uk/ospa-project/ospaexperience.html. Actors were recruited to role play clients at each station and provided with a written scenario about their character, comprising information for them to discuss with the candidate and further background information that could be used by the actor if asked for by the candidate. The written content of each station was separately specified for actors, TEPs and assessors.

Candidates were provided with an information sheet about who they would meet in each station, which was sent to them by email $24-48$ hours prior to the OSPA assessment. 
Candidates were advised that they were not expected to spend a lot of time preparing.

Assessors were provided with the background information for candidates and actors and additionally a calibrated mark scheme. Prior to the OSPAs taking place, training sessions were provided for assessors and actors were briefed on their role.

Each station lasted for ten minutes. At the start of each station, the TEP entered the room, a video camera was switched on, and the assessment began. An assessment co-ordinator was responsible for time keeping and after 8 minutes gave a reminder (via a walkie-talkie placed in each room) of " 2 minutes remaining". At the end of the 10 minutes, candidates heard the words "end station, it is now time for feedback". There then followed 5 minutes for the assessor to provide feedback (two strengths and one improvement suggestion) and ask TEPs for their own reflections on the session. After 15 minutes, the prompt "change station, switch off video recorder" was given and candidates left the room. TEPs were then given 5 minutes to familiarise themselves with the scenario background information before moving to the next station. This was repeated until candidates had visited all four stations.

The assessor present during each scenario was a university tutor who evaluated the TEP's performance using a pre-agreed calibrated mark sheet. The mark sheet covered a range of areas: communication skills, perspective taking, information gathering and synthesis, management and professional integrity. The TEP's skill level in each was rated as either 'competent' or as an 'area to develop'. The mark sheet also included space to highlight any strengths or improvement suggestions as supporting evidence. A supervisor who was not known to the TEP examined the video content at a later date and provided audio file feedback for candidates. 


\section{Research Rationale}

The aims of the current evaluation were to examine the views of university tutors and participating TEPs on the OSPA assessment process. The research questions posed were as follows:

(1) What do university tutors, who have been involved in the OSPAs, consider to be the strengths and weaknesses of this form of assessment?

(2) Following the experience of taking part, what are TEP views of the OSPAs as a method of assessing professional competence?

\section{Method}

\section{Design}

The research adopted a survey-based approach, using paper-based and online questionnaires to ascertain tutor and TEP views about the OSPAs. Cohen, Manion and Morrison (2011) described how "surveys gather data at a particular point in time with the intention of describing existing conditions" (p.256). Questionnaires were chosen to collect data to gain information from a geographically dispersed audience. These have the advantage that they provide a relatively efficient means of accessing information about attitudes, values and beliefs and provide anonymity for informants, which encourages openness. However, data may be affected by the characteristics of the respondents, for example, their memory, experience and knowledge and the likelihood of a social desirability response bias (Robson, 2002). The questionnaires were designed to collect both qualitative and quantitative data, through the use of open-ended questions and Likert-based rating scales. 


\section{Participants}

In order to address the research questions, views were sought from both groups of participants. To address the first research question, academic and professional tutors at the three universities who had assessed TEPs were asked to complete a questionnaire immediately after the OSPAs. All 12 assessors took part, four from each university. Six were female, six were male. Of the 12 tutors, three had worked in their university post for between 2 and 4 years, three for between 5 and 7 years and six for 8 years or more.

To address the second research question, 31 out of the 34 Year 2 TEPs who took part in the OSPAs at the three participating universities responded to the online questionnaire, representing a self-selecting sample. Seven participants were male and 24 were female. All were aged between 25 and 35 years.

\section{Procedure}

\section{Academic and Professional Tutors Questionnaire}

Immediately after the OSPAs, university tutors were asked to complete a paperbased questionnaire. Respondents were asked to rate how well they considered the OSPA exercise worked as an assessment approach, highlighting the positive features and any limitations observed. Opinion was sought on the marking scheme and recommended changes for improving the relevance, authenticity and content of the four scenarios used. They were also asked about possible advantages of and potential barriers to utilising OSPAs more extensively in TEP assessment. Response to a series of statements presented in Table 1 were rated using a 5 point Likert scale. 
Two TEP representatives from each university had an instrumental role in supporting the authors with the development of the TEP questionnaire. This was made available online and set up in Opinio (an online survey tool). Online questionnaires have the advantage of being cost effective (Yun \& Tumbro, 2000), time efficient and accessible to geographically distant participants (Evans \& Mathur, 2005; Lefever, Dal \& Matthiasdottir, 2007). In addition, data entry is carried out by, and can be completed at a convenient time for the participant making it more straightforward to tabulate and analyse (Evans \& Mathur, 2005).

Data were collected over a six-week period following the OSPAs. Respondents were asked to rate statements about: the validity of the OSPAs as an assessment tool and learning experience, relevance to their training, realism of the scenarios, usefulness of pre-assessment information about the scenarios and to what extent the OSPAs provoked anxiety, boosted confidence or developed competence. Additionally, views were sought about TEPs' experience of participating in the OSPAs, the potential contribution of the OSPAs to EP practice and ways of improving the OSPAs.

\section{Data Analysis}

Data from open questions were subject to content analysis using Atlas.ti (2004). Atlas.ti is a software tool that is designed to help with the analysis of qualitative data (such as interview transcriptions, e-mail correspondence, textual data; Friese, 2012). Content analysis is a technique of dividing units of communication into categories in order to interpret meaning (Hsieh \& Shannon, 2005; Vaismoradi, Turnumen, \& Bondas, 2013). Carrying out content analysis involves two strands: identifying key, substantive points; and putting them into categories (Gillham, 2007). The process of content 
analysis subjects the data to the following phases: preparation (immersion in the data to gain a sense of the whole picture); organising the data by creating categories of codes under headings and sub-headings; and reporting the process and results using categories, conceptual maps and a story line (Elo \& Kyngas, 2008). Data from open questions were scrutinised by the third author and coded into the emergent categories. These categories were then moderated by the first author, to achieve consensus on the categorisation and coding. Closed responses were counted and the results converted to percentages and displayed in numerical tables.

\section{Results}

Findings from tutor and TEP questionnaire responses are presented in the sections below. Identified categories are presented in italics.

\section{Academic and Professional Tutor Responses}

Tutors were asked to respond to a series of statements about the impact of the OSPAs. Results are shown in Table 1. 
Table 1. Participating university tutor evaluation of the OSPAs

\begin{tabular}{|c|c|c|c|c|c|}
\hline Statement & Disagree & $\begin{array}{c}\text { Marginally } \\
\text { Disagree }\end{array}$ & $\begin{array}{l}\text { Neither Agree nor } \\
\text { Disagree }\end{array}$ & $\begin{array}{l}\text { Marginally } \\
\text { Agree }\end{array}$ & Agree \\
\hline $\begin{array}{l}\text { The arrangements for the OSPAs } \\
\text { worked smoothly and without any } \\
\text { significant hitch }\end{array}$ & 0 & $\begin{array}{c}1 \\
(8 \%)\end{array}$ & 0 & 0 & $\begin{array}{c}11 \\
(92 \%)\end{array}$ \\
\hline $\begin{array}{l}\text { Students were given adequate time to } \\
\text { explore the complexity of the task they } \\
\text { were set }\end{array}$ & 0 & $\begin{array}{c}3 \\
(25 \%)\end{array}$ & $\begin{array}{c}1 \\
(8 \%)\end{array}$ & $\begin{array}{c}2 \\
(17 \%)\end{array}$ & $\begin{array}{c}6 \\
(50 \%)\end{array}$ \\
\hline $\begin{array}{l}\text { The instructions for the tasks were } \\
\text { clear and unambiguous }\end{array}$ & 0 & 0 & $\begin{array}{c}3 \\
(25 \%)\end{array}$ & $\begin{array}{c}7 \\
(58 \%)\end{array}$ & $\begin{array}{c}2 \\
(17 \%)\end{array}$ \\
\hline $\begin{array}{l}\text { The OSPAs portrayed authentic and } \\
\text { realistic scenarios }\end{array}$ & 0 & $\begin{array}{c}1 \\
(8 \%)\end{array}$ & $\begin{array}{c}1 \\
(8 \%)\end{array}$ & $\begin{array}{c}3 \\
(25 \%)\end{array}$ & $\begin{array}{c}7 \\
(58 \%)\end{array}$ \\
\hline $\begin{array}{l}\text { The OSPAs provided an appropriate } \\
\text { level of complexity }\end{array}$ & 0 & 0 & 0 & $\begin{array}{c}4 \\
(33 \%)\end{array}$ & $\begin{array}{c}8 \\
(67 \%)\end{array}$ \\
\hline $\begin{array}{l}\text { Trainees were not too stressed by the } \\
\text { experience to be able to fully exhibit } \\
\text { their skills and knowledge in this } \\
\text { context }\end{array}$ & 0 & $\begin{array}{c}2 \\
(17 \%)\end{array}$ & $\begin{array}{c}1 \\
(8 \%)\end{array}$ & $\begin{array}{c}6 \\
(50 \%)\end{array}$ & $\begin{array}{c}3 \\
(25 \%)\end{array}$ \\
\hline $\begin{array}{l}\text { The OSPAs are likely to have a } \\
\text { positive impact on teaching and } \\
\text { learning in the longer term }\end{array}$ & 0 & $\begin{array}{c}1 \\
(8 \%)\end{array}$ & $\begin{array}{c}1 \\
(8 \%)\end{array}$ & $\begin{array}{c}2 \\
(17 \%)\end{array}$ & $\begin{array}{c}8 \\
(67 \%)\end{array}$ \\
\hline $\begin{array}{l}\text { The assessment criteria for the } \\
\text { OSPAs were appropriate and relevant }\end{array}$ & 0 & 0 & $\begin{array}{c}3 \\
(25 \%)\end{array}$ & $\begin{array}{c}7 \\
(58 \%)\end{array}$ & $\begin{array}{c}2 \\
(17 \%)\end{array}$ \\
\hline $\begin{array}{l}\text { It is difficult to envisage the } \\
\text { assessment criteria being interpreted } \\
\text { differently by other assessors }\end{array}$ & $\begin{array}{c}2 \\
(17 \%)\end{array}$ & $\begin{array}{c}6 \\
(50 \%)\end{array}$ & $\begin{array}{c}1 \\
(8 \%)\end{array}$ & $\begin{array}{c}3 \\
(25 \%)\end{array}$ & 0 \\
\hline $\begin{array}{l}\text { The feedback arrangements to } \\
\text { trainees worked well }\end{array}$ & 0 & $\begin{array}{c}1 \\
(8 \%)\end{array}$ & $\begin{array}{c}3 \\
(25 \%)\end{array}$ & $\begin{array}{c}3 \\
(25 \%)\end{array}$ & $\begin{array}{c}5 \\
(42 \%)\end{array}$ \\
\hline $\begin{array}{l}\text { The criteria provided a good } \\
\text { framework for providing trainees with } \\
\text { feedback }\end{array}$ & 0 & 0 & $\begin{array}{c}4 \\
(33 \%)\end{array}$ & $\begin{array}{c}4 \\
(33 \%)\end{array}$ & $\begin{array}{c}4 \\
(33 \%)\end{array}$ \\
\hline $\begin{array}{l}\text { The use of video did not appear to } \\
\text { detract from the quality of the } \\
\text { consultation }\end{array}$ & $\begin{array}{c}1 \\
(8 \%)\end{array}$ & 0 & 0 & $\begin{array}{c}6 \\
(50 \%)\end{array}$ & $\begin{array}{c}5 \\
(42 \%)\end{array}$ \\
\hline $\begin{array}{l}\text { Do you think OSPAs could be used to } \\
\text { augment existing assessments of } \\
\text { professional competence on } \\
\text { placement? }\end{array}$ & $\begin{array}{c}1 \\
(8 \%)\end{array}$ & 0 & $\begin{array}{c}1 \\
(8 \%)\end{array}$ & $\begin{array}{c}3 \\
(25 \%)\end{array}$ & $\begin{array}{c}7 \\
(58 \%)\end{array}$ \\
\hline
\end{tabular}

In the main, tutor responses were positive, indicating that the OSPAs ran smoothly, instructions were clear, scenarios were authentic and provided an appropriate level of complexity, OSPAs were likely to have a positive impact on teaching and 
learning in the longer term, assessment criteria were appropriate and relevant and feedback arrangements worked well.

In addition, tutors were asked to rate how well they considered the OSPA exercise to have worked as an assessment approach. Ten of the twelve respondents $(84 \%)$ rated the exercise as having worked quite well or extremely well and two (17\%) recorded that they had no strong view, which was the mid-point on the five-point Likert scale.

Tutors were then asked to comment on what they thought to be the positive aspects of the OSPAs and limitations of the process. The responses were grouped into three categories: 1. Authenticity of scenarios, 2. Practical arrangements, 3. TEP response to the OSPAs.

Of the positive aspects of the OSPAs, tutor comments on the authenticity of scenarios, included "Great to be able to see TEPs demonstrating their skills in a more authentic situation than role play with other TEPs" (Tutor 3) and "OSPAs are an excellent way to look at TEP performance in a standardised scenario" (Tutor 12). Positive comments about the practical arrangements including the structure, organisation, time keeping and assessment framework included: "The assessment framework was clear and helpful in terms of framing feedback" (Tutor 11). Tutors reported that the TEP response to the OSPAs had generally been positive, for example commenting that "Trainees appeared mostly relaxed and engaged well" (Tutor 2) and that a "...good standard of communication skills was shown by trainees overall" (Tutor 1).

Of the limitations of the OSPAs, some tutors questioned the authenticity of scenarios, noting that success was dependent on the skills of the actor: "It does depend on the knowledge and ability of the actor to be convincing" (Tutor 11). Another stated 
"...with the best will in the world, it remains quite artificial" (Tutor 4). Comments about practical arrangements focused mainly on the 10 minute time frame allowed for each scenario, which one tutor stated was unrealistic and not long enough to enable the TEP to explore the scenario in sufficient depth: "Time constraints very evident - put limits on trainee's capacity to fully explore underlying issues in terms of consultee's core constructs" (Tutor 7). In addition, one tutor noted that there was "...too much to think about as assessor in time given" (Tutor 6). Comments on the TEP response to the OSPAs focused around anxiety, with one tutor stating that "...the build up to the day was stressful for some of the trainees" (Tutor 1).

\section{Trainee Educational Psychologist Responses}

TEPs were asked to rate on a scale of 1 (strongly disagree) to 5 (strongly agree) to what extent they thought the OSPAs were a valid assessment of skills in the following domains - communication, perspective taking, information gathering, case management and professional integrity. Responses are shown in Table 2.

Table 2. TEP views on the OSPAs by domain

\begin{tabular}{lccccc}
\hline \multicolumn{1}{c}{ Skills } & $\begin{array}{c}\mathbf{5} \\
\text { strongly } \\
\text { agree }\end{array}$ & $\begin{array}{c}\mathbf{4} \\
\text { agree }\end{array}$ & $\begin{array}{c}\mathbf{3} \\
\text { neutral }\end{array}$ & $\begin{array}{c}\mathbf{2} \\
\text { disagree }\end{array}$ & $\begin{array}{c}\mathbf{1} \\
\text { strongly } \\
\text { disagree }\end{array}$ \\
\hline a. skills in communication & 5 & 22 & 1 & 2 & 1 \\
b. skills in perspective taking & $16.13 \%$ & $70.97 \%$ & $3.23 \%$ & $6.45 \%$ & $3.23 \%$ \\
c. skills in information & 2 & 20 & 7 & 1 & 1 \\
gathering and synthesis & $6.45 \%$ & $64.52 \%$ & $22.58 \%$ & $3.23 \%$ & $3.23 \%$ \\
d. case management skills & 1 & 20 & 6 & 2 & 2 \\
& $3.23 \%$ & $64.52 \%$ & $19.35 \%$ & $6.45 \%$ & $6.45 \%$ \\
e. professional integrity & 0 & 5 & 14 & 8 & 4 \\
& $0 \%$ & $16.13 \%$ & $45.16 \%$ & $25.81 \%$ & $12.9 \%$ \\
& 1 & 15 & 11 & 2 & 1 \\
\hline
\end{tabular}

All participants responded to the questions 
Most positively, $70 \%$ of respondents agreed or strongly agreed that the assessments were a valid assessment of skills in communication and perspective taking. At the other end of the scale only $16 \%$ of respondents agreed ( $0 \%$ agreeing strongly) that the OSPAs were a valid assessment of case management skills, with nearly half (45\%) remaining neutral and $25 \%$ disagreeing.

TEPs were also asked to comment on their experience of participating in the OSPAs. Findings are shown in Table 3.

Table 3. TEP evaluation of the OSPA experience

\begin{tabular}{|c|c|c|c|c|c|c|}
\hline Statement & $\begin{array}{l}5 \\
\text { strongly } \\
\text { agree }\end{array}$ & $\begin{array}{c}4 \\
\text { agree }\end{array}$ & $\begin{array}{c}3 \\
\text { neutral }\end{array}$ & $\underset{\mathrm{e}}{\stackrel{2}{\text { disagre }}}$ & $\begin{array}{l}1 \\
\text { strongly } \\
\text { disagre } \\
\mathrm{e}\end{array}$ & Total \\
\hline $\begin{array}{l}\text { The content of the stations was relevant } \\
\text { to the programme }\end{array}$ & $\begin{array}{c}7 \\
22.58 \%\end{array}$ & $\begin{array}{c}23 \\
74.19 \%\end{array}$ & $\begin{array}{c}1 \\
3.23 \%\end{array}$ & $\begin{array}{c}0 \\
0 \%\end{array}$ & $\begin{array}{c}0 \\
0 \%\end{array}$ & $\begin{array}{c}31 \\
100 \%\end{array}$ \\
\hline The role players were realistic & $\begin{array}{c}7 \\
22.58 \%\end{array}$ & $\begin{array}{c}15 \\
48.39 \%\end{array}$ & $\begin{array}{c}6 \\
19.35 \%\end{array}$ & $\begin{array}{c}1 \\
3.23 \%\end{array}$ & $\begin{array}{c}2 \\
6.45 \%\end{array}$ & $\begin{array}{c}31 \\
100 \%\end{array}$ \\
\hline $\begin{array}{l}\text { The information provided prior to the } \\
\text { OSPAs matched the station scenarios }\end{array}$ & $\begin{array}{l}4 \\
13.33 \%\end{array}$ & $\begin{array}{c}15 \\
50 \%\end{array}$ & $\begin{array}{c}6 \\
20 \%\end{array}$ & $\begin{array}{l}4 \\
13.33 \%\end{array}$ & $3.33 \%$ & $\begin{array}{c}31 \\
100 \%\end{array}$ \\
\hline $\begin{array}{l}\text { The OSPAs were a good learning } \\
\text { experience }\end{array}$ & $\begin{array}{l}4 \\
13.33 \%\end{array}$ & $\begin{array}{c}18 \\
60 \%\end{array}$ & $\begin{array}{l}4 \\
13.33 \%\end{array}$ & $\begin{array}{c}3 \\
10 \%\end{array}$ & $\begin{array}{c}1 \\
3.33 \%\end{array}$ & $\begin{array}{c}31 \\
100 \%\end{array}$ \\
\hline $\begin{array}{l}\text { The OSPAs made me feel excessively } \\
\text { anxious }\end{array}$ & $\begin{array}{c}4 \\
12.9 \%\end{array}$ & $\begin{array}{c}10 \\
32.26 \%\end{array}$ & $\begin{array}{c}6 \\
19.35 \%\end{array}$ & $\begin{array}{c}9 \\
29.03 \%\end{array}$ & $\begin{array}{c}2 \\
6.45 \%\end{array}$ & $\begin{array}{c}31 \\
100 \%\end{array}$ \\
\hline $\begin{array}{l}\text { Having advance information about the } \\
\text { scenarios did not help my performance in } \\
\text { the OSPAs }\end{array}$ & $\begin{array}{c}2 \\
6.45 \%\end{array}$ & $\begin{array}{l}5 \\
16.13 \%\end{array}$ & $\begin{array}{c}3 \\
9.68 \%\end{array}$ & $\begin{array}{c}13 \\
41.94 \%\end{array}$ & $\begin{array}{c}8 \\
25.81 \%\end{array}$ & $\begin{array}{c}31 \\
100 \%\end{array}$ \\
\hline The OSPAs were a fair assessment & $\begin{array}{c}0 \\
0 \%\end{array}$ & $\begin{array}{l}18 \\
60 \%\end{array}$ & $\begin{array}{c}8 \\
26.67 \%\end{array}$ & $\begin{array}{c}3 \\
10 \%\end{array}$ & $\begin{array}{c}1 \\
3.33 \%\end{array}$ & $\begin{array}{c}30 \\
100 \%\end{array}$ \\
\hline I felt poorly prepared for the OSPAs & $\begin{array}{c}0 \\
0 \%\end{array}$ & $\begin{array}{c}4 \\
12.9 \%\end{array}$ & $\begin{array}{c}6 \\
19.35 \%\end{array}$ & $\begin{array}{c}18 \\
58.06 \%\end{array}$ & $\begin{array}{c}3 \\
9.68 \%\end{array}$ & $\begin{array}{c}31 \\
100 \%\end{array}$ \\
\hline $\begin{array}{l}\text { The feedback provided about my } \\
\text { performance on the OSPAs matched my } \\
\text { self-assessment }\end{array}$ & $\begin{array}{c}0 \\
0 \%\end{array}$ & $\begin{array}{c}24 \\
80 \%\end{array}$ & $\begin{array}{c}5 \\
16.67 \%\end{array}$ & $\begin{array}{c}0 \\
0 \%\end{array}$ & $\begin{array}{c}1 \\
3.33 \%\end{array}$ & $\begin{array}{c}30 \\
100 \%\end{array}$ \\
\hline $\begin{array}{l}\text { The OSPAs do not translate well into EP } \\
\text { training }\end{array}$ & $3.23 \%$ & $\begin{array}{c}3 \\
9.68 \%\end{array}$ & $\begin{array}{c}8 \\
25.81 \%\end{array}$ & $\begin{array}{c}18 \\
58.06 \%\end{array}$ & $3.23 \%$ & $\begin{array}{c}31 \\
100 \%\end{array}$ \\
\hline $\begin{array}{l}\text { Overall the OSPAs were a worthwhile } \\
\text { exercise }\end{array}$ & $\begin{array}{c}2 \\
6.45 \%\end{array}$ & $\begin{array}{c}20 \\
64.52 \%\end{array}$ & $\begin{array}{c}6 \\
19.35 \%\end{array}$ & $\begin{array}{c}3 \\
9.68 \%\end{array}$ & $\begin{array}{c}0 \\
0 \%\end{array}$ & $\begin{array}{c}31 \\
100 \%\end{array}$ \\
\hline $\begin{array}{l}\text { Incorporating OSPAs into EP training } \\
\text { would be beneficial }\end{array}$ & $\begin{array}{c}3 \\
9.68 \%\end{array}$ & $\begin{array}{c}16 \\
51.61 \%\end{array}$ & $\begin{array}{c}10 \\
32.26 \%\end{array}$ & $\begin{array}{c}2 \\
6.45 \%\end{array}$ & $\begin{array}{c}0 \\
0 \%\end{array}$ & $\begin{array}{c}31 \\
100 \%\end{array}$ \\
\hline
\end{tabular}


Undertaking the OSPAs has helped me develop competence in working with young people aged 16-25

Following the OSPAs, I feel more confident about working with young people aged 16-25

$\begin{array}{cccccc}1 & 4 & 7 & 12 & 7 & 31 \\ 3.23 \% & 12.9 \% & 22.58 \% & 38.71 \% & 22.58 \% & 100 \% \\ & & & & & \\ 2 & 4 & 4 & 13 & 8 & 31 \\ 6.45 \% & 12.9 \% & 12.9 \% & 41.94 \% & 25.81 \% & 100 \%\end{array}$

Feedback from the statements was generally positive, with the majority of TEPs agreeing to a greater or lesser degree that the content of the OSPAs was relevant and that the OSPAs were a good learning experience. Similarly, TEPs generally reported feedback matched self-assessment, that the OSPAs were a worthwhile exercise and that they should be incorporated into EP training. TEPs were less confident the OSPAs had helped develop competence and confidence in working with young people aged 16-25.

TEPs were asked to provide any further relevant qualitative information about their experience of the OSPAs. Responses were content-analysed, with sample responses reported in Table 4 . Where both positive responses and limitations/improvements suggestions were received, examples of each are provided. 
Table 4. TEP content analysed comments on the experience of the OSPAs

\begin{tabular}{|c|c|c|}
\hline Experience of the OSPAs & No. & $\begin{array}{r}\% \text { Total } \\
\text { Response }\end{array}$ \\
\hline 16-25 curriculum - positive comments & & \\
\hline $\begin{array}{l}\text { 'Before undertaking the OSPAS research I felt quite anxious but the } \\
\text { experience itself was a very positive one and actually boosted my } \\
\text { confidence for working in the 16-25 age range' (Trainee 14) } \\
16-25 \text { curriculum - limitations }\end{array}$ & 2 & 2.3 \\
\hline $\begin{array}{l}\text { 'did not feel that the OSPAs provided any learning in relation to } \\
\text { working with the 16-25 age range'(Trainee 16) }\end{array}$ & 8 & 9.2 \\
\hline Actors - positive comments & & \\
\hline $\begin{array}{l}\text { 'The actors played their roles well and were friendly out of the role } \\
\text { play situations'(Trainee 21) }\end{array}$ & 5 & 5.75 \\
\hline Actors - limitations & & \\
\hline $\begin{array}{l}\text { 'The actors often seemed lacking in background knowledge and } \\
\text { appeared quite uneasy during the scenarios when faced with the } \\
\text { prospect of improvising' (Trainee 19) }\end{array}$ & 4 & 4.6 \\
\hline Anxiety provoking? No & & \\
\hline $\begin{array}{l}\text { 'The OSPAs were less stressful than I was expecting' (Trainee 5) } \\
\text { Anxiety provoking? Yes }\end{array}$ & 2 & 2.3 \\
\hline $\begin{array}{l}\text { 'Before undertaking the OSPAS research I felt quite anxious but the } \\
\text { experience itself was a very positive one' (Trainee 14) }\end{array}$ & 7 & 8.05 \\
\hline Background information - positive comments & & \\
\hline $\begin{array}{l}\text { 'I think it was useful to have the information before the OSPAs to } \\
\text { be able to prepare and reduce my anxiety. It also meant that it was } \\
\text { more realistic to practice as you would normally have some } \\
\text { background information before starting work' (Trainee 15) } \\
\text { Background information - limitations }\end{array}$ & 3 & 3.45 \\
\hline $\begin{array}{l}\text { 'having the pre-information hindered what I would normally have } \\
\text { done, which would be to try to clarify the problem' (Trainee 10) }\end{array}$ & 5 & 5.75 \\
\hline Feedback - positive comments & & \\
\hline $\begin{array}{l}\text { 'I found the feedback useful and that it matched my own self- } \\
\text { assessment' (Trainee 5) }\end{array}$ & 12 & 13.8 \\
\hline $\begin{array}{l}\text { The immediate feedback was useful and I look forward to having } \\
\text { the written and video feedback to reflect upon' (Trainee 12) }\end{array}$ & & \\
\hline $\begin{array}{l}\text { 'Good to get some feedback about practice - rarely have on } \\
\text { placement' (Trainee 17) } \\
\text { Feedback - limitations }\end{array}$ & & \\
\hline $\begin{array}{l}\text { 'I would like to know how I was graded and what was written about } \\
\text { me during each scenario' (Trainee 1) } \\
\text { 'Sometimes the feedback reflected on what you were not able to } \\
\text { achieve in the } 10 \text { minutes, which is not entirely helpful as this } \\
\text { underestimates what would be done in actual practice' (Trainee } \\
28)\end{array}$ & 6 & 6.9 \\
\hline
\end{tabular}


Format/Assessment - positive comments

'Everyone involved in the delivery and feedback worked in a

supportive, nurturing way' (Trainee 24)

Format/Assessment - limitations

'I do think that role plays in general are a good way to practice our

skills, but I would prefer less formal opportunities for this '(Trainee

3)

Pre OSPA practise

'It may have been helpful to see a DVD clip of an EP / course tutor

and an actor in an unrelated scenario so that we could see for ourselves what might be expected and the criteria that would be used to judge our performance' (Trainee 22)

Timings - limitations

'Given that the situations were staged and had a tight time limit I

am not sure how much my performance in the stations is similar to my real practice and therefore am unsure about how valid the improvement suggestions would be for developing my practice on placement' (Trainee 20)

Validity/Realism of Scenario - positive comments

'I felt that the topics and role players were good' (Trainee 8)

Validity/Realism of Scenario - limitations

'I do not think they are as valid as being observed during a consultation on placement as the video and set up nature of the scenario is not realistic' (Trainee 1)

'While the actors were good, removing the consultation from the 'context' that would normally be present made it feel harder' (Trainee 15)

Worthwhile? Yes

'I thought that the OSPAs were a worthwhile experience...I can't think of a better way to guarantee specific experiences across placements.' (Trainee 6)

'the process was helpful in aiding reflection on professional skill development' (Trainee 19)

'I felt that OSPA stations mainly assessed skills in rapport building, information gathering, and communication skills' (Trainee 16)

Worthwhile? No

'I did not learn anything from the OSPAs and do not feel they were particularly worthwhile as a learning exercise, although as an assessment exercise I can understand their purpose.' (Trainee 7) 
TEPs commented on a range of issues. The highest number of comments received related to the benefits and limitations of feedback e.g. "Good to get some feedback about practice - rarely have on placement" (Trainee 17) and "I would like to know how I was graded and what was written about me during each scenario" (Trainee 1) followed by responses indicating how worthwhile the OSPAs were e.g. "the process was helpful in aiding reflection on professional skill development" (Trainee 19). Additionally, some TEPs suggested that the assessments were a valuable way of gaining experience and increasing confidence working with 16-25 post-school populations, for example, "Before undertaking the OSPAs research I felt quite anxious but the experience itself was a very positive one and actually boosted my confidence for working in the 16-25 age range." (Trainee 14). It is interesting to note that in most categories, data indicated both positive features and limitations, or areas for development.

Asked about how the experience of the OSPAs could be improved in future years, responses were coded into four categories: Standardisation, Feedback, Format and Scheduling.

In terms of Standardisation one TEP commented that there was some confusion "...about whether the OSPAs are testing our knowledge or our consultation skills" (Trainee 6). Others observed that a full and detailed briefing for the actors was important as they needed "... a greater understanding of the context in which they would likely end up in the given situations in real life" (Trainee 4). TEPs also commented, as did the tutors, on the importance of ensuring "...consistency of marking/feedback between tutors" (Trainee 11).

Feedback from actors was posited as potentially helpful (“...some initial feedback can be helpful and reassuring" (Trainee 17), but that timing of feedback was 
of key importance as there was a risk that this could be potentially “...off-putting - for instance affecting performance in the subsequent scenarios" (Trainee 17).

There were indications that the format of the OSPAs could be adapted to make the experience seem less daunting. For example, one TEP remarked "The experience seemed very formal... Is there any way you could make the atmosphere and procedures more relaxed?" (Trainee 2) while another reported that "anxiety could be reduced by not having a tutor in the room as it is being videoed" (Trainee 6).

\section{Discussion}

This study reports the evaluation of OSPAs piloted at three initial training programmes through ascertaining the views of tutors and TEPs through a questionnairebased survey design. The overall experience of the OSPAs was generally judged favourably by the participating academic and professional tutors and TEPs. This supports feedback on student experience carried out by other researchers (Yap et al., 2012; Troncon, 2004; Alinier, 2003; Hodges et al., 1999; Biran, 1991; Hodder et al., 1989; Black \& Harden, 1986). Tutors and TEPs agreed that OSPAs were a valid and fair assessment of the skills used by EPs. As noted in earlier studies (Yap et al., 2012; Alinier, 2003; Hodges et al. 1999), the assessments were considered to provide good learning opportunities and realistic scenarios. TEPs reported that the feedback they received after the OSPAs was helpful to them as a reflection on their practice and for professional development. This is in accordance with studies showing the feedback from OSCEs to be advantageous (Biran, 1991; Harris \& Miller, 1990; Hodder et al., 1989; Black \& Harden, 1986).

Tutors commented that time constraints were a limiting factor, both for TEPs having to work within a 10-minute time frame, and for assessors having too much to 
assess in a short amount of time. This concurs with previous studies that reported the time allowed at each station was inadequate (Troncon, 2004; Yap et al., 2012). The anxiety experienced by some students participating in live assessments has been reported in earlier studies (Yap et al, 2012; Rushforth, 2007; Bartfay et al., 2004; Troncon, 2004). However, it should be noted that the OSPAs were designed to provide TEPs with formative performance feedback and that it had no bearing on progression on their course, unlike the OSCEs in medical training which are summatively assessed and therefore failure affects course progression. Some researchers have argued that student stress makes the OSCE more valid, as "real world" practice is also stressful (Bartfay et al., 2004; Bujack, McMillan, Dwyer \& Hazleton, 1999), and that students themselves have reported valuing the OSCE process despite the stress experienced (Stroud, Smith, Edlund \& Erkel, 1999; Bujack et al., 1999). In this evaluation both tutors and TEPs recognised that the process could be anxiety provoking, but TEP statements suggest that for many the experience had been a positive one which boosted their confidence. Within the evaluation, some TEPs noted that it would have been useful to have had more OSPA practice prior to undertaking the assessment in order to become familiar with the format. This in line with findings by Yap et al. (2012) which suggested a lack of mock-examinations was perceived as detrimental by students.

Whilst care was taken to ensure consistency of assessment criteria, through the use of a standardised marking scheme, concerns remained about how reliably these were interpreted by tutors (also observed by Yap et al., 2012. The concerns about the reliability of the scale suggest the need for further calibration and standardisation. Tutors feedback indicated that whilst OSPAs provide a useful means of appraising competence, they should be used in conjunction with other assessments methods, a 
position supported by others (McKinley \& Boulet, 2004; Carraccio \& Englander, 2000; Miller, 1990).

Overall the potential of the OSPA as a useful teaching tool was highlighted by participants, with some suggesting it could be incorporated into TEP training, as in other professional training programmes (Yap et al., 2012; Sloan et al., 1996). Use of the OSPA video by TEPs to support self-reflection and professional development using methods such as Video Enhanced Reflective Practice (VERP; Kennedy, Landor, \& Todd, 2015) is one future potential development. The limitations of the study include that it was questionnaire based research, the value of which may be affected by responses from participants based on social desirability, rather than their true feelings or beliefs (Robson, 2002). The researchers were the TEPs' supervisors and therefore the TEPs may have been circumspect in what they reported. Similarly, tutors were reporting on an intervention set up by colleagues and may have wanted to respond favourably and positively. Although participants were assured of anonymity and confidentiality they may have been concerned that their comments would make them identifiable. Finally, OSPAs can never substitute for interactions that take place in the real world context of educational psychology service delivery and therefore are open to critique with regard to authenticity.

The results of this evaluation indicate that the medical OSCE can be transported to educational psychology and that there is value in continuing to develop and review the adapted model of the OSPA at university centres. Future directions include involving both educational psychology educators and practitioners in authoring a stock of professionally authenticated scenarios for future use. These will need to be carefully calibrated to ensure that the criteria for competent performance are defined clearly and 
unambiguously, to ensure good inter-rater reliability. Other developments include consideration of OSPAs for summative assessments, as opposed to current formative assessments. In addition, the involvement of practising EPs as partners to university tutors in making assessments at each OSPA station is important for external validation and dissemination. It is through professional partnerships between training providers and placement providers that competent practice can be defined in line with workforce needs, reliable and valid assessments developed further and the quality of educational psychology training enhanced to ensure that it is fit for purpose into the future. 


\section{References}

Alinier, G. (2003). Nursing students' and lecturers' perspectives of objective structured clinical examination incorporating simulation. Nurse Education Today, 23(6), 419-426.

Alinier, G., \& Alinier, N. (2006). Design of an objective assessment tool to evaluate students' basic electrical engineering skills: the OSTE. Journal for the Enhancement of Learning and Teaching, 3(1), 57-63.

Atkinson, C., Dunsmuir, S., Lang, J. \& Wright, S. (2015). Developing a competency framework for the initial training of educational psychologists working with young people aged 16-25. Educational Psychology in Practice, 31(2), 159-173. doi:10.1080/02667363.2015.1004038

ATLAS.ti 5.0, 2nd Edition (2004), Thomas Muhr, Scientific Software Development Berlin.

Bartfay, W. J., Rombough, R., Howse, E., \& Leblanc, R. (2004). Evaluation. The OSCE approach in nursing education. The Canadian Nurse, 100(3), 18-23.

Biran, L. A. (1991). Self-assessment and learning through GOSCE (group objective structured clinical examination). Medical Education, 25, 475-479. doi: 10.1111/j.1365-2923.1991.tb00100.x

Black, N. M.\& Harden, R. M. (1986).Providing feedback to students on clinical skills by using the Objective Structured Clinical Examination. Medical Education, 20, 48-52. doi: 10.1111/j.1365-2923.1986.tb01041.x

Bujack, L., McMillan, M., Dwyer, J., \&Hazleton, M. (1991). Assessing comprehensive nursing performance: the objective structured clinical assessment (OSCA). Part 2: Report of the evaluation project. Nurse Education Today, 11, 248-255. 
Carraccio, C., \& Englander, R. (2000). The objective structured clinical examination. Archives of Pediatric and Adolescent Medicine, 154, 736-741. doi:10.1001/archpedi.154.7.736

Cohen L., Manion, L. and Morrison, K. (2011) Research Methods in Education (7th edition) London: Routledge-Falmer.

Elo, S, \& Kyngäs H. (2008). The qualitative content analysis process. Journal of Advanced Nursing,62, 107-115. doi:10.1111/j.1365-2648.2007.04569.x

Evans, J. \& Mathur, A. (2005) "The value of online surveys", Internet Research, Vol. 15 Iss: 2, pp. 195 - 219. doi:10.1108/10662240510590360

Friese, S. (2012). Qualitative Data Analysis with Atlas.ti. Sage Publications.

Gillham, B. (2007). Developing a questionnaire (2nd ed). London: Continuum Publishing.

Gonsalvez, C.J., \& Freestone, J. (2007). Field supervisors' assessment of trainee performance: are they reliable and valid? Australian Psychologist, 42 (1), 23-32. doi:10.1080/00050060600827615

Harden, R., Stevenson, M., Wilson Downie, W.\&Wilson, G. (1975). Assessment of clinical competence using objective structured examination. British Medical Journal, 447-451. doi:10.1136/bmj.1.5955.447

Harris, I. B., \& Miller, W. J. (1990). Feedback in an objective structured clinical examination by medical students serving as patients, examiners, and teachers. Academic Medicine, 65, 433-434. doi:10.1097/00001888-199007000-00002

Hodges, B., Hanson, M., McNaughton, N., \& Regehr, G. (2002). Creating, monitoring, and improving a psychiatry OSCE. Academic Psychiatry, 26(3), 134-161. doi:10.1176/appi.ap.26.3.134 
Hodges, B., Regehr, G., McNaughton, N., Tiberius, R., \& Hanson, M. (1999). OSCE checklists do not capture increasing levels of expertise. Academic Medicine, 74(10), 1129-1134. doi:10.1097/00001888-199910000-00017

Hsieh, H-F. \& Shannon, S.E. (2005). Three approaches to qualitative content analysis, Qualitative Health Research, 15 (9), 1277-1288. doi:10.1177/1049732305276687

Humphris, G. M., \& Kaney, S. (2001). Assessing the development of communication skills in undergraduate medical students. Medical education, 35(3), 225-231. doi:10.1046/j.1365-2923.2001.00869.x

Jewell, D. (1988). Learning through examinations: use of an objective structured clinical examination as a teaching method in general practice. The Journal of the Royal College of General Practitioners, 38(316), 506-508.

Kennedy, H., Landor, M., \& Todd, L. (2015). Video Enhanced Reflective Practice: Professional development through attuned interactions. London: Jessica Kingsley

Lefever, S, Dal, M. \& Matthiasdottir, A. (2007). Online Data Collection in Academic Research: Advantages and Limitations. British Journal of Educational Technology, Vol.38(4), p.574-582

MacRae, H.M., Cohen, R., Regehr, G., Reznick, R., \& Burnstein, M. (1997). A new assessment tool: the patient assessment and management examination. Surgery, 122, 335-44. doi:10.1016/S0039-6060(97)90025-8

McKinley, D., and Boulet, J. (2004).The effects of task sequence on examinee performance. Teaching and Learning in Medicine, 16 (1), 18-22. doi:10.1207/s15328015tlm1601_5 
McKnight, J., Rideout, E., Brown, B., Clieska, D., Patton, D., Rankin, J., \& Woodward, C. (1987). The objective structured clinical examination: an alternative approach to assessing student clinical performance. Journal of Nursing Education, 26(1), $39-41$.

Malik, S. L., Manchanda, S. K., Deepak, K. K., \& Sunderam, K. R. (1988). The attitudes of medical students to the objective structured practical examination. Medical education, 22(1), 40-46.

Malik, S. L., Manchanda, S. K., Deepak, K. K., \& Sunderam, K. R. (1988). The attitudes of medical students to the objective structured practical examination. Medical education, 22(1), 40-46.

Miller, G. E. (1990). The assessment of clinical skills/competence/performance. Academic medicine, 65(9), S63-7.doi:10.1097/00001888-199009000-00045

Newble, D. (2004). Techniques for measuring clinical competence: objective structured clinical examinations. Medical education, 38(2), 199-203. doi:10.1111/j.13652923.2004.01755.x

Rao, R. (2005) OSCEs in Psychiatry. Ed: R Rao. London: Gaskell

Roberts, J., \& Brown, B. (1990). Testing the OSCE: a reliable measurement of clinical nursing skills. The Canadian journal of nursing research= Revue canadienne de recherche en sciences infirmières, 22(1), 51.

Robson, C. (2002). Real World Research: A Resource for Social Scientists and Practitioner-Researchers ( $2^{\text {nd }}$ Ed). Blackwell Publishing.

Ross, M., Carroll, G., Knight, J., Chamberlain, M., Fothergill-Bourbonnais, F., \& Linton, J. (1988). Using the OSCE to measure clinical skills performance in nursing. Journal of advanced nursing, 13(1), 45-56. doi:10.1111/j.13652648.1988.tb01390.x 
Rushforth, H.E. (2007). Objective structured clinical examination (OSCE): Review of literature and implications for nursing education. Nurse Education Today, 27, 481-490. doi:10.1016/j.nedt.2006.08.009

Schuwirth, L. W., \& Van der Vleuten, C. P. (2003). The use of clinical simulations in assessment. Medical Education, 37(s1), 65-71. doi:10.1046/j.13652923.37.s1.8.x

Scott, T. L., Pachana, N. A., \& Sofranoff, K. (2011). Survey of current curriculum practices within Australian post-graduate clinical training programs: Students' and program directors' perspectives. Australian Psychologist, 46(2), 77-89.

Sloan, D.A., Donnelly, M.B., Schwartz, R.W., Felts, J.L., Blue, A.V., and Strodel, W.E. (1996). The use of the Objective Structured Clinical Examination (OSCE) for evaluation and instruction in graduate medical education. Journal of Surgical Research, 63, 225-30. doi:10.1006/jsre.1996.0252

Sloan, D.A., Donnelly, M.B., Schwartz, R.W., \& Strodel, W.E. (1995). The Objective Structured Clinical Examination: the new gold standard for evaluating postgraduate clinical performance. Annals of Surgery, 222, 735-42. doi:10.1097/00000658-199512000-00007

Stroud, S. D., Smith, C. A., Edlund, B. J., \& Erkel, E. A. (1999). Evaluating clinical decision-making skills of nurse practitioner students. Clinical excellence for nurse practitioners: The International Journal of NPACE, 3(4), 230.

Troncon, L. E. D. A. (2004). Clinical skills assessment: limitations to the introduction of an" OSCE" (Objective Structured Clinical Examination) in a traditional Brazilian medical school. São Paulo Medical Journal, 122(1), 12-17. doi:10.1590/S1516-31802004000100004 
Tsai, T. C. (2004). Using children as standardised patients for assessing clinical competence in paediatrics. Archives of disease in childhood, 89 (12), 1117-1120. doi:10.1136/adc.2003.037325

Vaismoradi, M., Turnumen, H., \& Bondas, T. (2013). Content analysis and thematic analysis: Implications for conducting a qualitative descriptive study. Nursing and Health Sciences, 15, 398-405. doi:10.1111/nhs.12048

Watson, R., Stimpson, A., Topping, A., \& Porock, D. (2002). Clinical competence assessment in nursing: a systematic review of the literature. Journal of advanced nursing, 39(5), 421-431. doi:10.1046/j.1365-2648.2002.02307.x

Woods, K. (2013). 'In This Together': Developing University-Workplace Partnerships in Initial Professional Training for Practitioner Educational Psychologists. In O. McNamara, J. Murray \& M. Jones (Eds.) Teacher Learning in the Workplace: widening perspectives on practice and policy. Part 2: Insights from practice across professions and nations. London: Springer, pp. 87-102.

Yap, K., Bearman, M., Thomas, N. \& Hay, M. (2012). Clinical psychology students' experiences of a pilot objective structured clinical examination. Australian Psychologist, 47, 165-173. doi:10.1111/j.1742-9544.2012.00078.x

Yun, G. W. and Trumbo, C. W. (2000), Comparative Response to a Survey Executed by Post, E-mail, \& Web Form. Journal of Computer-Mediated Communication, 6: 0. doi:10.1111/j.1083-6101.2000.tb00112.x 